Rocznik Andragogiczny

\title{
Hanna Liberska, Alicja Malina, Dorota Suwalska-Barancewicz (red.), Zmiany w życiu współczesnych ludzi i ich konteksty, Wydawnictwo Diffin, Warszawa 2016, ss. 406
}

Po raz kolejny pod redakcją pracowników Zakładu Psychologii Społecznej i Badań nad Młodzieżą Uniwersytetu Kazimierza Wielkiego w Bydgoszczy ukazała się monografia poświęcona szeroko rozumianym problemom życia współczesnego człowieka. Książkę można zatem potraktować jako piątą część cyklu monografii dotyczącego funkcjonowania współczesnych. Wcześniej ukazały się tomy dotyczące radzenia sobie $z$ wielością ról i zadań, wyzwań i zagrożeń czekających na współczesnych w XXI wieku, funkcjonowania młodych $\mathrm{w}$ dobie zmian czy problemów współczesnych małżeństw i rodzin ${ }^{1}$. W recenzowanej pozycji problemy zostały potraktowane interdyscyplinarnie, przez co uniknięto niebezpiecznej jednostronności w postrzeganiu omawianych zmian.

Główną perspektywą, wokół której skonstruowana jest oś książki, jest kontekst. Zatem tytułowe Zmiany $w$ życiu wspótczesnych zostały poddane analizie zgodnie z przeświadczeniem, że człowiek rozwija się w określonym kontekście. Jest zatem istotą bio-socjo-kulturową, która żyje w określonych warunkach, przestrzeni, czasie czy systemie. Konteksty owych oddziaływań płyną z wielu stron, tak samo jak dotyczą wielu sfer życia człowieka. Analizując zamieszczone tu teksty, można zadać sobie pytanie o relację owych zmian z pełnym, zdrowym i wszechstronnym rozwojem jednostki oraz jego możliwościami. W odpowiedzi na to pytanie pomagają prace autorek i autorów, którzy są przedstawicielami różnych dyscyplin: psychologii, pedago-

${ }^{1}$ Do tej pory ukazały się: Dylematy wspótczesnych ludzi: radzenie sobie z wielościq ról i zadań, Warszawa 2015; Współcześni ludzie wobec wyzwań i zagrożeń XXI wieku, Warszawa 2014; Funkcjonowanie współczesnych młodych ludzi w zmieniającym się świecie, Warszawa 2012 wszystkie pod redakcją Hanny Liberskiej, Alicji Maliny oraz Doroty Suwalskiej-Barancewicz, a także: Wybrane problemy wspótczesnych matżeństw i rodzin (2011) pod redakcją Hanny Liberskiej i Alicji Maliny. 
giki, socjologii, politologii, medycyny, prawa. Tym samym zarysowuje się interdyscyplinarny kontekst oddziaływań i relacji pomiędzy współczesnym człowiekiem a jego otoczeniem. Łatwo jednak dostrzec ważną psychologiczno-pedagogiczną oś dominanty pośród omawianych aspektów.

Ważnym problemem wyszczególnionym we wskazanej monografii jest funkcjonowanie w kontekście potrzeby przynależności i realizacji funkcji bezpieczeństwa. Jednostka w obliczu bycia częścią danej komórki społecznej staje wobec konkretnych wyzwań i problemów, którym musi sprostać, zarówno na poziomie indywidualnym, jak i zespołowym. Pośród tych kontekstów oddziaływań, wyszczególniono takie komórki społeczne i mikrospołeczeństwa jak rodzina, placówki opiekuńczo-wychowawcze, rodziny zastępcze, wspólnoty religijne czy szkoła.

Nie tylko współczesności, a także współczesnym dyskursom i dociekaniom często zarzuca się unikanie poszukiwania odpowiedzi na pytania trudne. Łatwo dostrzec, że i te aspekty zostały zauważone przez autorów, którzy zadają sobie pytanie o funkcjonowanie w świetle choroby, radzenie sobie z przeciwnościami czy ze stresem. Dostrzeżono również problemy dotyczące pewnych dysfunkcji, m.in. życia wobec współuzależnienia czy zaburzeń funkcjonowania współczesnej rodziny.

$\mathrm{Na}$ dużą uwagę zasługują tematy szczególnie gorące społecznie, które są chętnie poruszane przez współczesne media. Do takich zaliczyłabym życie niepłodnych par, przewlekłe zmęczenie, kobiecość i ciało w świetle ciąży, problem absolwentów na rynku pracy czy miłości w świecie aplikacji. To niezwykle istotne, by monografia poświęcona współczesności nadążała za zmianami i uwzględniała wątki czy aspekty, które są gorącymi społecznie tematami, ważnymi nie tylko dla środowisk uniwersyteckich. Duże znaczenie w komunikacji współczesnych odgrywa język. W kontekście języka znalazły się teksty niezwykle interesujące i oryginalne (jeśli chodzi o wyszczególnione aspekty) jednocześnie, poświęcone m.in. nazwom banków w XXI wieku czy obrazie polskości w filmach Wojciecha Smarzowskiego.

Wątkiem, który zainteresował mnie w sposób szczególny, jest kultura nowości w kontekście wolności. To aspekty, które oscylują wokół problemów socjologii edukacji czy ogólnie dyskursów krytycznych (nie krytykanckich). To ważne, aby dostrzegać pułapki pozornej wszechobecnej wolności. Nie pominięto tu aspektu zniewolenia w kulturze wolności czy problemu tożsamości uwikłanej we współczesne konteksty.

Recenzowana pozycja stanowi interesujący przegląd kontekstów funkcjonowania człowieka w świetle zmian. Choć na początku wielość ta może napawać niepokojem, to z pewnością owa interkontekstualność stanowi 
duży walor omawianej pracy. Pośród kontekstów znalazły się relacje przemian z funkcjonowaniem współczesnych, rodzicielstwo, sytuacje trudne, aspekty medyczne, antropologiczno-społeczne, instytucje szkolne, język czy media. Człowiek nie został przez autorów potraktowany wyłącznie jako przedmiot oddziaływań, ale równoprawny kreator życia społecznego, współuczestnik i współtwórca zmian jednocześnie, który z owymi zmianami musi sie nieustannie mierzyć na nowo. Tytułowe konteksty, chociaż dookreślają specyfikę, czas i miejsce występowania owych zmian, nie sprawiają, że stają się one łatwiejszymi dla współczesnych ludzi.

Iwona Murawska 